Faculty of Mechanical Engineering

University of Belgrade

Serbia

Ivan Milošević ${ }^{* *}$

College of Hotel Management, Belgrade

Serbia

\title{
THE SEMANTIC MOTIVATION OF PLANT-RELATED IDIOMATIC EXPRESSIONS IN ENGLISH AND SERBIAN
}

\begin{abstract}
The aim of the paper is to investigate the semantic motivation of a set of English and Serbian plant-related idiomatic expressions, to ascertain the cognitive mechanisms that motivate their semantic structure and, ultimately, to contrast them, using the cognitive semantic view of idioms. Our analysis shows that in both languages the conceptual metaphors based on the source domain of PLANTS play a very important role in the semantics of the analysed idiomatic expressions, accompanied by the conventional knowledge, the conceptual metonymy and image schemas. The concluding part discusses the observed similarities in the cognitive mechanisms which motivate the semantics of the analysed expressions, but also reflects upon certain differences between the two languages in terms of the idiomatic expression constituents.
\end{abstract}

Key words: idiomatic expressions, plants, semantic motivation, cognitive semantics, English, Serbian

\section{Introduction}

Due to their specific structure and syntactic behaviour, idioms have posed a rather intriguing research topic for decades. The so-called traditional views of idioms regarded them as largely non-transparent (Makkai 1972; Chomsky 1980; Palmer 1981). Contrary to this approach, cognitive linguists have put forth the idea that the nature of idioms is systematic, semantically motivated and (partially) compositional (Lakoff 1987; Gibbs 1994; Kövecses and Szabó 1996). This view also has implications for idiom comprehension, as shown by ground-breaking psycholinguistic research in

\footnotetext{
*Faculty of Mechanical Engineering, University of Belgrade, Kraljice Marije 16, 11120 Belgrade, Serbia; e-mail: tvesic@mas.bg.ac.rs

${ }^{* *}$ College of Hotel Management, Kneza Višeslava 70, 11000 Belgrade, Serbia; e-mail: ivan.milosevic@vhs. edu.rs
} 
the field (Gibbs and Nayak 1989; Gibbs, Nayak and Cutting 1989; Gibbs and O'Brien 1990; Gibbs 1992; Gibbs et al. 1997), as well as for teaching idioms in foreign languages, most notably English (Boers 2000, 2001, 2011; Boers and Demecheleer 2001; Boers, Demecheleer and Eyckmans 2004; Deignan, Gabrys and Solska 1997; Kövecses 2001).

The focus of this paper is on a set of English and Serbian plant-related idiomatic expressions in which one of the constituent elements is a lexeme denoting plants, more specifically, the plant itself, plant parts, stages in the plant lifecycle and plant cultivation. The aim is to investigate the semantic motivation of these expressions, to ascertain the cognitive mechanisms that motivate their semantic structure and, finally, to contrast them in terms of their structure and motivation. The theoretical framework of the paper rests on the research findings of Gibbs $(1993,1994)$ and Kövecses and Szabó (1996), who view idioms as linguistic expressions whose meaning is not completely arbitrary, but partially motivated. The approach has proven to be fruitful in recent studies of idioms (e.g. Benczes 2002, Csábi 2003, Milošević 2014).

The analysis included twenty-five plant-related idioms in total (twelve idioms in English and thirteen in Serbian). Bearing in mind a vast number of idioms in both languages which may be labelled as "plant-related", the list of idioms was compiled primarily focusing on those with the constituent lexemes denoting certain general aspects related to the source domain of PLANTS, such as plant parts, plant growth and plant cultivation. We started from the already available lists of English and Serbian lexemes that denote these elements of the PLANT domain and searched the representative dictionaries of the two languages for the idioms that contained these specific lexemes (for more details, see section four). The corpus for the study comprised the examples of use of the analysed idioms found in the representative electronic corpora of the two languages (the British National Corpus for English, the Corpus of the contemporary Serbian language for Serbian), more specifically, 216 examples in English and 559 examples in Serbian.

The paper is organised in six sections. In section two, we provide an overview of the definitions of idioms offered in the literature and discuss the so-called traditional and cognitive semantic approaches to idioms. The PLANT source domain and the related conceptual metaphors are presented in the third section. Section four contains a detailed description of the idiomatic expressions included in the study. The results of the analysis are given in the fifth section, while the final, sixth section provides concluding remarks. 


\section{Approaches to idiom semantics}

According to most scholars, idioms or idiomatic expressions ${ }^{1}$ are multiword expressions whose meaning is difficult to predict based on the individual meanings of their constituent components ${ }^{2}$. In comparison to some other linguistic units, their semantic structure is more difficult to define, analyse and explain. Idioms can include a wide range of linguistic expressions, such as phrasal compounds (red herring), phrasal verbs (to give in), binominals (spick and span) or frozen similes (as cool as a cucumber) (Gibbs 1994: 269). Since they encompass "a mix bag" of expressions (Kövecses and Szabó 1996: 328), they have not been the top priority in the linguistic research, especially in the pre-cognitivist era of language study. Nevertheless, the advent of Cognitive Linguistics has instigated an array of investigations of idioms that focused primarily on their semantic structure.

The so-called traditional view of idiomatic expressions (Makkai 1972; Chomsky 1980; Palmer 1981) has not been very fruitful in regard to the semantic analysis of idioms. These authors have concentrated on other aspects instead, such as idiom syntax, thus neglecting any systematicity in the semantic structure of those units. Moreover, idioms have been regarded as "dead" metaphors listed in the mental lexicon of a speaker (Gibbs 1994: 270). The cognitive view of idioms, proposed by authors such as Lakoff (1987), Gibbs (1994) and Kövecses and Szabó (1996) disputed the claim of idioms being frozen expressions in the mental lexicon of a speaker, and put forward an idea of their lively and creative nature. Idioms are thus viewed as a part of our conceptual world, belonging both to the language and the mind. As a result, they are perceived to be semantically motivated, partly compositional and analysable. Their semantic motivation directly stems from numerous conceptual correspondences between the elements which exist in the pre-verbal and non-verbal world.

Such perception of idioms has introduced the concept of idiom compositionality, which has become the key tool in their semantic analysis. It implies that the semantic structure of idiomatic expressions can be partially broken down to the meaning of their constituent components which contribute to the overall meaning of the idiom they make up ${ }^{3}$. This view has cast a new light on the analysability of idioms. Gibbs (1994: 278) argues that "many idiomatic phrases appear to be analysable or decomposable, with the meanings of their parts contributing independently to their overall figurative meaning".

\footnotetext{
${ }^{1}$ The authors of the current paper are using these two terms as synonyms.

2 "Most views of idioms agree that idioms consist of two or more words and that the overall meaning of these words is unpredictable from the meanings of the constituent words." (Kövecses and Szabó 1996: 328). ${ }^{3}$ For a detailed elaboration of the differences between the traditional and cognitive views in the study of idioms see Milošević 2014: 157.
} 
Research has shown that the meaning of idioms is motivated by various cognitive mechanisms, such as conceptual metaphor, conceptual metonymy and conventional knowledge (e.g. Kövecses and Szabó 1996). Conceptual metaphor implies "understanding one conceptual domain in terms of another domain" (Kövecses 2002: 4), whereby the domain whose elements are used for conceptualizing the other domain is called the source domain, and the more abstract domain, structured in terms of the elements of the source domain, is called the target domain. Conceptual metonymy refers to the use of an entity to denote another entity which is logically related to the first one (Rasulić 2010); finally, conventional knowledge encompasses "the shared information that people in a given culture have concerning a conceptual domain" (Kövecses and Szabó 1996: 338).

Evidence of semantic analysability and compositionality of the idiom structure has disputed the traditional view of idioms as "dead" metaphors in its strict, syntactic sense. Rather to the contrary, idioms are regarded as lively expressions, which can even motivate the making of new idioms. This feature of the semantic productivity of idioms is illustrated by Gibbs (1994: 283), who argues that "the individual words in many idioms can be changed to create new idiomatic meanings that are based on both the original idiom's meaning and the new words (break the ice - shatter the ice)". The same author (Gibbs 1994: 282) introduces the feature of lexical flexibility in idioms since in many cases "individual lexical items can be changed without serious disruption of these phrases (button your lip can be changed into fasten your lip)".

All the above-mentioned studies support the claim that the meaning of idiom constituent elements contributes to the overall meaning of the idiom (Gibbs 1994: 278). As a result, we have opted to employ the cognitive approach in our analysis since we find it more adequate to explaining the intricate nature of idiom semantics.

\section{The source domain of PLANTS}

The domain of PLANTS is one of the universal and most pervasive domains of human experience (Kövecses 2002). Previous studies have demonstrated that the elements of this domain are used for profiling numerous abstract notions in different languages (Kövecses 1999, 2002; Vesić 2007; Vesić Pavlović 2008). The conceptual mappings from the PLANT domain are also productive in the semantic motivation of English phrasal verbs whose constituent verb is the lexeme that belongs to the domain of PLANTS (Milošević and Vesić Pavlović 2017).

Previous research has shown that the main conceptual metaphor which is used in the structuring of abstract concepts via the source domain of PLANTS is COMPLEX ABSTRACT SYSTEMS ARE PLANTS, based on two primary metaphors: ABSTRACT STRUCTURE IS PHYSICAL STRUCTURE and ABSTRACT DEVELOPMENT IS PHYSICAL GROWTH (Kövecses 1999: 
180). It comprises a number of submetaphors related to different aspects of human experience with plants, such as plant parts (e.g. ORIGINS OR CAUSES LEADING TO EFFECTS ARE PARTS OF PLANTS FROM WHICH OTHER PLANTS GROW, THE BENEFICIAL CONSEQUENCES OF A PROCESS ARE THE FRUITS OR THE CROP OF A PLANT, POTENTIAL OR SOURCES OF FUTURE EVENTS ARE SEEDS), stages in plant growth (e.g. THE INITIAL STAGES OF DEVELOPMENT ARE THE BEGINNINGS OF GROWTH, THE BEST STAGE IN THE PROGRESS OR DEVELOPMENT OF A COMPLEX SYSTEM IS THE FLOWERING OF A PLANT, THE SUCCESSFUL OR APPROPRIATE DEVELOPMENT OF A COMPLEX SYSTEM IS THE HEALTHY GROWTH OF A PLANT, THE UNSUCCESSFUL OR INAPPROPRIATE DEVELOPMENT OF A COMPLEX SYSTEM IS THE UNHEALTHY GROWTH OF A PLANT, THE QUICK DEVELOPMENT OF A LARGE NUMBER OF THINGS IS THE QUICK GROWTH OF A LARGE NUMBER OF SHOOTS AND LEAVES) or plant cultivation (e.g. TO START OR TO CREATE A COMPLEX SYSTEM IS TO SOW THE SEED, TO MAINTAIN OR TO TAKE CARE OF A COMPLEX SYSTEM IS TO CULTIVATE A PLANT, REDUCING COMPLEX SYSTEMS IS MAKING PLANTS SMALLER) (Kövecses 1999: 175178). This metaphor also forms a part of the GREAT CHAIN OF BEING cultural model, which arranges living beings and their properties on a vertical scale from the "higher" beings above to the "lower" beings below (Lakoff and Turner 1989). The model is active whenever one part of the chain is used to conceptualise another (e.g. plants for humans). Based on the results of previous studies, it may be expected that these conceptual metaphors would play an important role in the semantic motivation of the plant-related idiomatic expressions under investigation.

\section{Plant-related idiomatic expressions in English and Serbian}

As stated in the Introduction, a large number of idiomatic expressions may be subsumed under the category of the "plant-related" idiomatic expressions in both languages. Since it was not possible to analyse all these expressions in a single paper, we selected a specific set which includes plant-related idiomatic expressions in English and Serbian with the constituent lexemes that denote either the plant itself, plant parts, stages in plant growth or plant cultivation. In selecting these categories, we relied on the previous studies of the polysemy of lexemes belonging to the source domain of PLANTS, which have distinguished between several categories of lexemes, such as those denoting the plant itself, plant parts, stages in plant growth, stages in plant cultivation, specific plants etc. (cf. Deignan 1995, Kövecses 1999, Vesić 2007).

Starting from the previously compiled lists of English and Serbian lexemes which describe various aspects related to the domain of PLANTS (for a detailed list, see Vesić 2007), we searched the representative dictionaries (Macmillan Dictionary for English, Rečnik srpskoga jezika (RSJ) for Serbian) for the idiomatic expressions listed under the entries for the selected lexemes that denote the plant itself, plant parts, plant growth and plant cultivation, bearing in mind the definitions and the features of 
idiomatic expressions mentioned earlier. The obtained sets of expressions included in the analysis are presented in Tables 1-2. In the majority of cases, we have a parallel expression in both English and Serbian in terms of the same overall meaning. Hence, English and Serbian idiomatic expressions are presented in parallel in the tables, although, in some cases, the individual constituent lexemes denoting the elements of the source domain of PLANTS are not the same.

Table 1. shows the list of analysed English and Serbian idiomatic expressions that contain the lexemes denoting the plant itself (tree) or plant parts (root, branch, bud, leaf, thorn, straw in English, and koren 'root', grana 'branch', list 'leaf', trn 'thorn', slamka 'straw' in Serbian). There are two idioms from this group where there is no parallel plant-related idiom in terms of meaning in both languages - the English expressions root and branch (in Serbian, there is an equivalent lexeme korenito 'from the root', but it is an adverb, not an idiom) and Serbian tikva bez korena 'a gourd without a root'.

\begin{tabular}{|l|l|}
\hline \multicolumn{1}{|c|}{ ENGLISH } & \multicolumn{1}{|c|}{ SERBIAN } \\
\hline root and branch & \\
\hline to put down roots & pustiti korenje \\
\hline & tikva bez korena \\
\hline to nip in the bud & saseći (preseći, zatrti) u korenu \\
\hline (at) the top of the tree & $\begin{array}{l}\text { pasti } \\
\text { (spasti, dospeti, doći, spustiti se) na niske grane }\end{array}$ \\
\hline to turn over a new leaf & okrenuti novi list \\
\hline to be a thorn in somebody's flesh/side & biti trn u oku \\
\hline to shake (tremble, shiver) like a leaf & tresti se (drhtati) kao prut \\
\hline to grasp (clutch) at straws & hvatati se za slamku \\
\hline
\end{tabular}

Table 1. Idiomatic expressions containing the lexemes that denote plant parts or plant itself

As can be seen in Table 1, there are cases in which idiomatic expressions in two languages contain different plant-related lexemes but have the same meaning, such as to nip in the bud and saseći (preseći, zatrti) $u$ korenu (the difference being in the nouns bud in English and koren in Serbian) and to shake (tremble, shiver) like a leaf and tresti se kao prut (including the noun leaf in English and prut in Serbian). A particularly interesting case in this regard is the pair of idioms (at) the top of the tree in 
English and pasti na niske grane 'to fall onto low branches' in Serbian. The meaning of these two expressions might be described as opposite but rather complementary, since the English idiom refers to achieving the highest position in society or one's career, and the Serbian one implies just the opposite. They accordingly feature the lexemes denoting different parts of a tree - the English idiom includes the top, while the Serbian includes branches at the bottom (niske grane).

The selected idiomatic expressions which contain lexemes that denote plant growth and cultivation are shown in Table 2. The lexemes describing the processes involved in plant growth featured in the idioms include English verb to sprout and Serbian nicati 'to sprout' and rasti 'to grow'; those denoting plant cultivation comprise the verbs to plant, to reap and to sow in English and Serbian verbs sejati 'to sow', posejati 'to finish sowing', žeti 'to harvest', ubrati 'to pick' and obrati 'to pick'. The meaning of the idiomatic expressions is paralleled in both languages, with one exception, that of obrati zelen bostan 'to pick green watermelon', which occurs only in Serbian.

\begin{tabular}{|l|l|}
\hline \multicolumn{1}{|c|}{ ENGLISH } & \multicolumn{1}{|c|}{ SERBIAN } \\
\hline to sprout (appear, grow, spring up) like mushrooms & nicati (rasti) kao pečurke (posle kiše) \\
\hline to plant the seed of doubt & posejati seme sumnje \\
\hline you reap what you sow/as you sow & kako seješ, tako ćeš $i$ žeti \\
\hline to reap the fruit(s) (of one's labours) & ubrati plodove \\
\hline & obrati zelen bostan \\
\hline
\end{tabular}

Table 2. Idiomatic expressions containing the lexemes that denote plant growth and cultivation

\section{Research results}

Upon the analysis of the examples featuring the selected idiomatic expressions, it has been found that the mechanisms which motivate their semantics in English and Serbian include conceptual metaphor, conceptual metonymy and conventional knowledge, as well as image metaphors and image schemas in certain cases.

The presentation of the results is organised in the following way. First, we present the cases in which conceptual metaphors play a dominant role in the semantics of the analysed expressions. Then we deal with the group of cases which are simultaneously motivated by several cognitive mechanisms. Finally, we focus on two cases where there is an image schematic transformation at the core of the idiom meaning. We also provide a contrastive analysis of the semantic features of the investigated idiomatic 
expressions. The meanings of idioms are illustrated by the examples from the used corpora, but, due to constraints of space, only selected examples are shown. Less relevant parts of examples are shortened in certain cases, which is indicated by the [...] symbol.

\subsection{Idiomatic expressions motivated by conceptual metaphors}

In this subsection, we first discuss the group of expressions that include the concept of RоOт, namely to put down roots and root and branch in English and tikva bez korena in Serbian. Generally speaking, the meaning of these idioms is motivated by the conceptual metaphor ORIGINS OR CAUSES LEADING TO EFFECTS ARE PARTS OF PLANTS FROM WHICH OTHER PLANTS GROW (Kövecses 1999).

In English, putting down roots implies becoming a part of the community by making friends and taking part in local activities (Macmillan), and a similar meaning is featured in Serbian, "to become common, entrenched somewhere" (RSJ). Based on the examples found in the corpora, we may say that, in this case, the conceptual metaphor ORIGINS OR CAUSES LEADING TO EFFECTS ARE PARTS OF PLANTS FROM WHICH OTHER PLANTS GROW can be formulated as ORIGINS ARE ROOTS. The meanings of idioms are illustrated by the examples below.

(1) In some cases, because of our long waiting list, people have been here too long - they have married, put down roots and have children in school - and it would be unreasonable to send them back.

(2) U Severnoj Americi prošlo je dosta vremena pre nego što su Kinezi pustili korenje i osetili se dovoljno sigurni u sebe da postave pitanje svojih ljudskih prava u središte javnog interesa.

'It took long for the Chinese in North America to put down roots and feel confident enough to set the issue of their human rights in the centre of public interest.'

The idiom tikva bez korena (literally, "a gourd without a root") denotes people who have no influence or important contacts $(R S J)$. Similar to the previous two idioms, its meaning is motivated by the conceptual metaphor BACKGROUND IS A ROOT, since the influence or background is conceptualised as firm embeddedness in the soil achieved by the root in this case (3).

(3) Iako mladi, kreatori iz "Čumić dizajn distrikta" svakako nisu "tikva bez korena". Većina njih odavno je afirmisana kod nas i u svetu [...]. 'Although they are young, the fashion designers from the Čumić Design District are definitely not unknown. The majority of them have long been recognized both here and internationally $[\ldots .$.$] .'$ 
In English, the idiomatic expression root and branch contains the concepts of a root and a branch that are perceived as the basic parts of the plant from which other plants grow $(4,5)$. It is assumed that performing some activity in this way is done thoroughly, totally, usually associated with opposing or destroying something (Macmillan). This is related to the experience with plants which are destroyed completely if their roots and branches are removed. In this case, the metaphor structuring the meaning of this expression, ORIGINS OR CAUSES LEADING TO EFFECTS ARE PARTS OF PLANTS FROM WHICH OTHER PLANTS GROW, can be formulated as DESTROYING ORIGINS OR CAUSES OF SOMETHING IS REMOVING ROOTS AND BRANCHES.

(4) I would say just this: that having got the legislation it would be wise to proceed by exemplar, by experiment, by demonstration of success rather than trying to do a root and branch revolutionary approach.

(5) It is a sad day when we are grateful for not being abused in this house, but it's about all we have to be thankful for until this wretched system is altered, root and branch.

The next pair of analysed expressions, to nip in the bud and saseći u korenu, carries a similar meaning of stopping a bad situation before it becomes worse (Macmillan) or destroying, changing something completely (RSJ). This meaning is motivated by the conceptual metaphor THE INITIAL STAGES OF DEVELOPMENT ARE THE BEGINNINGS OF GROWTH (Kövecses 1999), which implies that stopping something in the initial stage of development (i.e. in the PLANT domain, when the plant produces roots or buds, which appear in the early stage of plant growth) means destroying it completely, as illustrated by $(6,7)$.

(6) Then let's nip this unpleasantness in the bud before it goes any further [...].

(7) Kako će već prvog dana utakmice u kojima igraju Srbi i Hrvati biti jedna iza druge policija u Melburnu je ponovo skrenula pažnju na norme ponašanja i odlučnost da saseče u korenu svaki incident.

'Since the games of the Serbs and Croats will be played one after another on the very first day, the Melbourne police have once again pointed to the rules of behaviour and their determination to nip every incident in the bud.'

The group of expressions featuring the lexemes that denote the processes and activities involved in plant growth and cultivation includes the notions of a seed, sowing and reaping. The expressions to sow the seed of doubt and posejati seme sumnje refer to starting a certain process that will have a particular result (Macmillan, $R S J)$. The meaning of these expressions relies on two conceptual metaphors with the source domain of PLANTS: TO START OR TO CREATE A COMPLEX SYSTEM IS TO SOW THE SEED 
and POTENTIAL OR SOURCES OF FUTURE EVENTS ARE SEEDS; FUTURE EVENTS ARE THE FUTURE GROWTH OF THE PLANT (Kövecses 1999), as illustrated by $(8,9)$.

(8) To further annoy his sister, Francis said: 'Anna is his granddaughter after all.' But the exchange had sown a tiny seed of doubt in his own mind [...].

(9) Oni su napravili, za prosečnog čitaoca, neku vrstu dajdžesta Solženjicina, Arona, Kestlera i Popera, i francuskoj publici pružili neka nova saznanja (nova za njih) i time ubacili seme sumnje u jednu stamenu i kompaktnu ideološku konstrukciju.

'They made, for the average reader, a kind of a digest of Solzhenitsyn, Aron, Koestler, and Popper, and provided some new insights (new to them) to the French audience, and thus sowed the seeds of doubt in a robust and compact ideological construction.'

The meaning of the idioms you reap what you sow and kako seješ, tako ćeš $i$ žeti is that someone will be rewarded for any good deeds they do and punished in a certain way if they do something bad (Macmillan, RSJ). This is communicated via the experience with cultivating plants in which the quality of seeds affects the quality of harvest/reaping. Hence, we have a similar underlying conceptual metaphor as in the previous case: POTENTIAL OR SOURCES OF FUTURE EVENTS ARE SEEDS; FUTURE EVENTS ARE THE FUTURE GROWTH OF THE PLANT (Kövecses 1999) $(10,11)$.

(10) She rejected the idea immediately: the Newleys deserved to reap as they had sowed.

(11) Tomčić kaže da na predsednika IDS-a Ivana Jakovčića može da se primeni narodna poslovica - "Kako je sejao, tako će i žnjeti”.

"Tomčić says that the proverb "What you reap is what you sow" can be used for the IDS President Ivan Jakovčić.'

The meaning of the idiomatic expressions to reap the fruits (of one's labours) and ubrati plodove refers to getting something as a result of what you do (Macmillan, $R S J)$, as shown by $(12,13)$. This meaning is motivated by the metaphor THE BENEFICIAL CONSEQUENCES OF A PROCESS ARE THE FRUITS OR THE CROP OF A PLANT (Kövecses 1999), since fruits come as the final stage in plant growth and cultivation, which demands a lot of previously invested effort.

(12) Until the internal combustion engine was fully 'harnessed' in the middle of this century, man depended upon the heavy horse to enable him to reap the fruits of his innovations.

(13) Ti si, oče, na svoje pronalaske utrošio godine rada i truda, a za svoje aparate i opite izdao preko 20.000 talira, a sada se predomišljaš da li da ubereš plodove svog rada. 
'Father, you have spent years labouring and investing in your inventions, and paid over 20,000 thalers for your equipment and experiments, and now you're not sure whether to reap the fruits of your labour.'

\subsection{Idiomatic expressions motivated by several conceptual mechanisms}

The idiomatic expressions to sprout like mushrooms and nicati kao pečurke (posle kiše) carry the meaning of a sudden appearance of something in great numbers. This meaning is motivated by THE QUICK DEVELOPMENT OF A LARGE NUMBER OF THINGS IS THE QUICK GROWTH OF A LARGE NUMBER OF MUSHROOMS metaphor (Kövecses 1999). Conventional knowledge also plays an important part in the motivation of these expressions since mushrooms are known for their rapid growth potential in a moist environment, which is additionally signalled in both expressions by adding the words in a wet field and posle kiše in the examples $(14,15)$.

(14) Like any bureaucracy given a green light, the Secret Intelligence Service grew like mushrooms in a wet field overnight.

(15) Doduše, otkako su naši teniseri postali svetske zvezde, u Srbiji niču teniski tereni kao pečurke posle kiše [...].

'Ever since our tennis players became world stars, tennis courts have sprouted like mushrooms after the rain in Serbia [...].'

The idiomatic expression obrati (zelen) bostan (literally translated as "to pick (green) watermelon") is rather informal and means to fare badly, to be punished for something that you did $(R S J)$. Its meaning is primarily motivated by the conceptual metaphor THE BENEFICIAL CONSEQUENCES OF A PROCESS ARE THE FRUITS OR THE CROP OF A PLANT (Kövecses 1999), which can be formulated as UNDESIRABLE CONSEQUENCES ARE UNRIPE FRUITS in this case $(16,17)$. Another mechanism that structures the meaning of this idiomatic expression is conventional knowledge. Watermelon is traditionally picked in the field when ripe. If picked green (especially by children), there is not much use of it. Therefore, children were often threatened with a certain punishment in case they picked it green.

(16) Danas je Engleska poznata po tome što na njenim stadionima nema ograde i zmeđu igrališta i gledališta, jer je svaki posetilac kupovinom ulaznice upoznat da je obrao zelen bostan ukoliko načini izgred.

'Today, England is well-known for not having a fence between the field and the audience in its stadiums, because every visitor is informed when purchasing a ticket that (s)he is not going to fare well if(s)he provokes an incident.' 
(17) A, znači tako, imao si dete a vešto si to prikrivao. Samo kada za to sazna tvoja žena, obrao si bostan.

'So, you have a kid and you've been hiding it successfully. When your wife finds out about it, you're a dead man.'

The idiomatic expressions to turn over a new leaf and okrenuti novi list have the meaning of starting to behave or act better or different than before (Macmillan, $R S J$ ). It may be argued that the speakers draw correspondences between a sudden and significant change in somebody's behaviour or attitude and an act of reading a book. In particular, it is about the conventional knowledge they have about the unknown, often unpredictable or even unexpected contents that can be read on the next page of a book. Furthermore, the semantic structure of this contrasted pair is additionally motivated via a metaphorical scenario in which the domain of Books is modelled based on the domain of PLANTS (A PART OF A BOOK IS A PART OF A PLANT).

(18) There was an immediate indication that he was prepared to turn over a new leaf.

(19) Nova vlast je okrenula novi list, u susret joj je krenuo i, manje-više, ceo razvijeni demokratski svet.

'The new government turned over a new leaf, and, more or less, the whole developed democratic world set out to greet it.'

The meaning of the idiomatic expressions to be a thorn in sb's flesh/side and biti trn $u$ oku refers to someone or something that keeps causing serious problems or that is annoying (Macmillan, RSJ). The idioms' semantic structure is predominantly motivated by the following conventional knowledge: if a thing such as a thorn is stuck in a person's body or flesh, or any sensitive body part (an eye, in the case of the Serbian idiom), it certainly causes a painful (at least, unpleasant) feeling. Additionally, the idioms' meaning is structured by the conceptual metonymy A THORN STANDS FOR A PROBLEM.

(20) Why on earth did you do that, Christina? The man has been a thorn in our side since the day he arrived three weeks ago.

(21) Ljudi koji dolaze u Beograd ne smeju nikome da budu trn u oku.

'People who come to Belgrade mustn't be a thorn in anyone's side.'

The meaning of the pair of idioms to shake (tremble, shiver) like a leaf and tresti se (drhtati) kao prut is structured via a combination of conventional knowledge and an image metaphor. Rather than mapping concepts, image metaphors map images (Lakoff and Turner 1989: 89), i.e. the structure of one domain is mapped onto the

\footnotetext{
${ }^{4}$ The Serbian noun prut denotes a thin wooden stick that is very flexible and difficult to break, usually coming from thin branches such as a willow-tree.
} 
structure of another domain, but instead of domains we have mental images (Lakoff and Turner 1989: 90). The specific image metaphor in this case relates the trembling of leaves in the wind with the shaking of a person. Namely, speakers draw parallels between the physical shaking of a person (as a result of fear, cold, etc.) and their conventional knowledge in the domain of PLANTS concerning the easy movement of some plant parts such as thin and supple branches (e.g. of a willow-tree) or leaves in the windy conditions $(22,23)$.

(22) She was trembling like a leaf and there he was, arrogantly amused and highly self-satisfied.

(23) Stari gospodin drhtao je kao prut, a zubi su mu cvokotali dok se oblačio. 'The old man was shaking like a leaf and his teeth rattled as he put his clothes on.'

\subsection{Idiomatic expressions motivated by an image schema}

Two pairs of analysed idiomatic expressions are partly motivated by image schemas. An image schema is defined in the literature as "a recurring, dynamic pattern of our perceptual interactions and motor programs that gives coherence and structure to our experience" (Johnson 1987: XIV). The list of image schemas provided by Johnson (1987) includes CONTAINER, PATH, CYCLE, FULL-EMPTY, PART-WHOLE, LINK, CENTREPERIPHERY, NEAR-FAR etc.

The idioms (at) the top of the tree and pasti (spasti, dospeti, doći, spustiti se) na niske grane refer to a person's social position in a hierarchy. They have in common the constituent components of a tree and a branch (Serbian grana), but the English idiom involves the concept of being up, while the Serbian implies falling down. Their meaning is thus predominantly structured by the image schema of VERTICALITY, coupled with the UP-DOWN orientation metaphors FAVOURABLE SOCIAL POSITION IS UP, UNFAVOURABLE SOCIAL POSITION IS DOWN (Rasulić 2004: 242).

As the examples below indicate $(24,25)$, the Serbian expression is broader in the scope of meaning, since the English expression is primarily associated with a person's position in a professional environment, whereas as the Serbian idiom has a much wider social context use.

(24) The term associate publisher was also, said RH chief executive Gail Rebuck, and appropriate one 'for someone who has come to the top of the tree'.

(25) Šarif Tomas je, po svoj prilici, pao na niske grane. Ako je ovde, druži se s najgorim ološem.

'Sharif Thomas has obviously hit the rock bottom. If he's here, he's hanging out with the worst scum.' 
Another pair of idiomatic expressions whose meaning is motivated by the image schema is the English to clutch/grasp at straws and Serbian hvatati se za slamku. Both have a similar meaning of trying hard to find a solution to a situation although you are aware that it does not exist (Macmillan, RSJ), as attested by examples $(26,27)$. This meaning is structured by both the image schema of SUPPORT and the conventional knowledge. The SUPPORT ${ }^{5}$ schema, that is, the concept of the physical support that humans look for when they lose ground or balance, is structurally embedded in the conceptual framework of the phrasal components (constituent phrases) of the contrasted idioms, that is, to clutch/grasp at in the English idiom and hvatati se za in the Serbian idiom. This physical imbalance is mapped onto the metaphorical domains regarding certain unstable, difficult, precarious situations humans can fall into. Additionally, the idioms' meaning is also motivated by the conventional knowledge that people have of straws, especially their feature of being "light", thus being an insufficient provider of the much-needed support people need in certain situations.

(26) In mid-October the Bank of England raised its discount rate - a belated attempt to stem the flood of credit it had itself created. The rise was a mere token, from 2 to 3 per cent, but people were so nervous they clutched at straws, assuring each other that now all would be well.

(27) Ovo naše podneblje i ovi ratovi su toliko pogodovali uplivu sekti, magijama i vračarama da se narod u očajanju hvatao za slamku i tražio prečicu do olakšanja i spokoja.

'This land of ours and these wars were so favourable to the rise of sects, magic and sorcerers that the people clutched at straws in despair and sought a shortcut towards relief and peace.'

\subsection{Additional semantic features of the analysed idioms}

When the analysed idioms are compared in terms of their semantic characteristics, there are both similarities and differences. There are cases in which the idiom constituent components are semantically identical in two languages (e.g. to reap the fruits, to sow the seed of doubt in English, ubrati plodove, posejati seme sumnje in Serbian). There are also cases where the overall meaning is the same but certain constituent components involve different plant parts (e.g. to nip in the bud and saseći u korenu). We have also recorded a case of lexical flexibility (to be a thorn in sb's flesh/side) with the nouns flesh and side being interchangeable, that is, lexically flexible, without any change in the overall meaning of the idiom. Moreover, we have detected several cases

\footnotetext{
${ }^{5}$ For more details about the supPoRT schema, see Vandeloise (1991: 186-209), Evans (2010: 241-243) and Milošević (2016: 37-41).
} 
of collocability, such as to shake (tremble, shiver) like a leaf, to sprout (appear, grow, spring up) like mushrooms in English or tresti se (drhtati) kao prut, saseći (preseći, zatrti) u korenu in Serbian, which imply that different near-synonymous constituent verbs can collocate with the idiom nucleus without a change in meaning.

In terms of semantic productivity, the examples for the new idiomatic meanings based on the original form of the analysed idioms were not found in the corpora we used. This was expected since we searched for the exact formulations. However, we should mention an interesting example of semantic productivity of one set of idioms found both in English and Serbian as a motto for the USAID Cooperation for Growth Project, aimed at "improving conditions for broad-based economic growth through improvements in the Serbian business enabling environment" (https://saradnja.rs/). The new idioms as we sow, so shall we grow and kako sejemo, tako ćemo i rasti are modelled on the Serbian phrase, kako seješ, tako ćeš $i$ žeti. All the examples of different semantic features of the investigated idioms listed and explained in the previous passage substantiate the claim that idioms can be perceived as "active" and "lively", not "dead" expressions.

\section{Conclusion}

The focus of the paper was the analysis of a set of English and Serbian idiomatic expressions which feature a lexeme from the domain of PLANTS, more specifically, a lexeme denoting the plant itself, plant parts and stages of plant growth and cultivation. We attempted to determine the conceptual mechanisms that are responsible for the motivation of these expressions in the light of the cognitive semantic theory of idioms.

Our analysis has shown that the semantic structure of these English and Serbian idioms is predominantly motivated by the following cognitive mechanisms: conceptual metaphor, conceptual metonymy, conventional knowledge and image-schematic transformations. This proves the importance of the notion of idiom analysability, partial motivation and compositionality, postulated by the researchers within the cognitive approach.

There is a high degree of cross-linguistic overlap between the semantic structure of the investigated English and Serbian idiomatic expressions. In other words, for all the analysed idioms, it has been shown that the same cognitive mechanisms structure their semantic motivation (e.g. to sprout like mushrooms vs nicati kao pečurke (posle kiše): both are motivated by the conceptual metaphor THE QUICK DEVELOPMENT OF A LARGE NUMBER OF THINGS IS THE QUICK GROWTH OF A LARGE NUMBER OF SHOOTS AND LEAVES/ MUSHROOMS).

When it comes to the specific mechanisms that motivate the meaning of the analysed idiomatic expressions in both English and Serbian, it can be argued that the 
key role is played by the conceptual metaphor. The underlying metaphors in these cases form a part of the COMPLEX ABSTRACT SYSTEMS ARE PLANTS metaphor and are systematic, since they are based on the metaphors that generally motivate the extension of meaning of the constituent idiom lexemes related to the plant itself, plant parts, plant lifecycle and stages in plant cultivation. Some of the analysed idiomatic expressions are simultaneously motivated by several cognitive mechanisms (Kövecses and Szabó 1996: 352), for instance, both conceptual metaphors and conventional knowledge (to sprout like mushrooms, nicati kao pečurke (posle kiše)), an image schema and a metaphor ((at) the top of the tree, pasti na niske grane), or conventional knowledge and a conceptual metonymy (to be a thorn in sb's flesh/side, biti trn u oku). The analysis has therefore substantiated the claims proposed by the cognitive linguistic authors that the semantic structure of idioms is partially analysable and compositional. This view is additionally corroborated by the cases of different semantic processes which the idioms under investigation undergo proving their "active" nature as a part of their semantic compositionality and motivation, such as lexical flexibility or collocability.

Still, the obtained results may be influenced by the fact that the selected plantrelated idiomatic expressions only included those with the constituent lexemes denoting the general aspects of the PLANT source domain; it may be argued that these form the part of universal human experience with plants, fairly identical in both analysed languages and cultures. The study did not comprise the idioms which feature specific plant terms, whose semantic motivation may be much more difficult to analyse and explain since it may be under the influence of a specific culture, i.e. as argued by Kövecses (2006: 333), some conceptual metaphors "may be entirely based on unique cultural phenomena". Hence, future studies should focus on other English and Serbian plant-related idioms, specifically those which contain the terms denoting specific plants (e.g. to be coming up roses, to wither on the vine, all oak and iron bound in English or biti manji od makova zrna, ne vredeti ni zrna boba, kad na vrbi rodi grožđe in Serbian), to establish whether those expressions are motivated by similar mechanisms and exhibit the same semantic features as the plant-related idiomatic expressions analysed here.

The majority of the idioms investigated in the paper may be deemed figurative (Boers 2001), which means that their meaning is motivated predominantly by the same conceptual metaphors that motivate the polysemy of the lexemes which form their constituent parts. Thus, the findings of the study may be particularly useful in teaching English idiomatic expressions related to plants to Serbian learners since there is a high degree of cross-linguistic and cross-cultural similarity in the motivation of these expressions, which should be made clear to learners whose native language is Serbian. This is in line with the suggestion given by Boers and Demecheleer (2001: 26) that "if the idiom has a high level of imageability, then encourage the learner to first infer its 
meaning from its lexical constituents and then test the hypothesis against the context", and after that provide a comparison with L1 equivalents. Hence, the results of the study may also be particularly useful in English language teaching.

\section{References}

Benczes, R. (2002). The semantics of idioms: a cognitive linguistic approach. The Even Yearbook, 5, 17-30.

Boers, F. (2000). Metaphor awareness and vocabulary retention. Applied Linguistics, 21(4), 553-571.

Boers, F. (2001). Remembering figurative idioms by hypothesizing about their origin. Prospect, 16(3), 35-43.

Boers, F. (2011). Cognitive semantic ways of teaching figurative phrases: An assessment. Review of Cognitive Linguistics, 9(1), 227-261.

Boers, F. and M. Demecheleer (2001). Measuring the impact of cross-cultural differences on learners' comprehension of imageable idioms. ELT Journal, 55(3), 255-262.

Boers, F., M. Demecheleer and J. Eyckmans (2004). Cross-cultural variation as a variable in comprehending and remembering figurative idioms. European Journal of English Studies, 8(3), 375-388.

Chomsky, N. (1980). Rules and Representations. New York: Columbia University Press.

Csábi, S. (2003). Polysemous words, idioms and conceptual metaphors: Cognitive linguistics and lexicography. In: A. Braasch and C. Povlsen (eds.), Proceedings of the Tenth Euralex International Congress, Copenhagen: Center for Sprogteknologi, 249-254.

Deignan, A. (1995). Collins Cobuild English Guides 7: Metaphor. London: Harper Collins.

Deignan, A., D. Gabrys and A. Solska (1997). Teaching English metaphors using cross-linguistic awareness-raising activities. ELT Journal, 51(4), 352-360.

Evans, V. (2010). From the spatial to non-spatial: The 'state' lexical concepts of in, on and at. In: V. Evans and P. Chilton (eds.), Language, Cognition and Space: The State of the Art and New Directions, London: Equinox Publishing Company, 215-248.

Gibbs, R. W. (1992). What do idioms really mean? Journal of Memory and Language, 31(4), 485-506. 
Gibbs, R. W. (1993). Why idioms are not dead metaphors. In: C. Cacciari and P. Tabossi (eds.), Idioms: Processing, structure, and interpretation, Hillsdale: Lawrence Erlbaum Associates, 57-77.

Gibbs, R. W. (1994). The Poetics of Mind. Cambridge: Cambridge University Press.

Gibbs, R. W. and J. E. O'Brien (1990). Idioms and mental imagery: The metaphorical motivation for idiomatic meaning. Cognition, 36(1), 35-68.

Gibbs, R. W. and N. P. Nayak (1989). Psycholinguistic studies on the syntactic behavior of idioms. Cognitive Psychology, 21, 100-138.

Gibbs, R. W., J. M. Bogdanovich, J. R. Sykes and D. J. Barr (1997). Metaphor in idiom comprehension. Journal of Memory and Language, 37(2), 141-154.

Gibbs, R. W., N. P. Nayak and C. Cutting (1989). How to kick the bucket and not decompose: Analyzability and idiom processing. Journal of Memory and Language, 28, 576-593.

Johnson, M. (1987). The Body in the Mind: The Bodily Basis of Meaning, Reason and Imagination. Chicago: University of Chicago Press.

Kövecses, Z. (1999). Metaphor: Does It Constitute or Reflect Cultural Models? In: G. Steen and R. Gibbs (eds.), Metaphor in Cognitive Linguistics, Amsterdam and Philadelphia: John Benjamins, 167-188.

Kövecses, Z. (2001). A cognitive linguistic view of learning idioms in an FLT context. Applied Cognitive Linguistics, 2, 87-115.

Kövecses, Z. (2002). Metaphor: A practical introduction. New York: Oxford University Press.

Kövecses, Z. (2006). Language, mind, and culture: A practical introduction. New York: Oxford University Press.

Kövecses, Z. and P. Szabó (1996). Idioms: A view from cognitive semantics. Applied Linguistics, 17(3), 326-355.

Lakoff, G. (1987). Women, Fire and Dangerous Things: What Categories Reveal About the Mind. Chicago: Chicago University Press.

Lakoff, G. and M. Turner (1989). More Than Cool Reason: A Field Guide to Poetic Metaphor. Chicago: The University of Chicago Press.

Makkai, A. (1972). Idiom structure in English. The Hague: Mouton.

Milošević, I. (2014). A cognitive insight into the semantics of idioms with the example of business English idioms. In: Z. Paunović (ed.), English Language and Literature Studies: Embracing Edges Proceedings, Beograd: Filološki fakultet, $155-164$.

Milošević, I. (2016). Frazni glagoli sa partikulama in, out, on i off u engleskom jeziku: kognitivnolingvistička analiza. Unpublished PhD Dissertation. Faculty of Philology, University of Belgrade. 
Milošević, I. and T. Vesić Pavlović (2017). A cognitive-linguistic investigation of English phrasal verbs related to plants. Facta Universitatis, Series: Linguistics and Literature, 15(2), 219-233.

Palmer, F. R. (1981). Semantics. Cambridge: Cambridge University Press.

Rasulić, K. (2004). Jezik i prostorno iskustvo: Konceptualizacija vertikalne dimenzije u engleskom i srpskohrvatskom jeziku. Beograd: Filološki fakultet.

Rasulić, K. (2010). Aspekti metonimije u jeziku i mišljenju. Theoria, 53(3), 49-70.

Vandeloise, C. (1991). Spatial Prepositions: A Case Study from French. Chicago: University of Chicago Press.

Vesić Pavlović, T. (2008). How do people sprout, blossom, ripen and wither? PEOPLE ARE PLANTS METAPHOR in English and Serbian. In: K. Rasulić and I. Trbojević (eds.), ELLSSAC Proceedings, Vol. I, Beograd: Filološki fakultet, 351-362.

Vesić, T. (2007). Metafore u engleskom i srpskom jeziku čiji je izvorni domen pojam BILJKE. Unpublished Master Thesis. Faculty of Philology. University of Belgrade.

\section{Sources}

British National Corpus. 2019. (10 April 2019) <http://corpus.byu.edu/bnc $>$.

Corpus of the contemporary Serbian language. 2013. Faculty of Mathematics, University of Belgrade. (15 April 2019) <http://korpus.matf.bg.ac.rs $>$.

USAID Projekat saradnje za ekonomski razvoj. 2019. USAID. (15 May 2019) $<$ https://saradnja.rs/ $>$.

\section{Dictionaries}

Macmillan: Macmillan Dictionary. 2009. Springer Nature Limited. (10 April 2019) $<\mathrm{https} / / / \mathrm{www} . \mathrm{macmillandictionary.com} />$.

RSJ: Nikolić, M. (ur.). (2007). Rečnik srpskoga jezika. Novi Sad: Matica srpska. 